\title{
Altering Physically Effective Fiber Intake Through Forage Proportion and Particle Length: Digestion and Milk Production ${ }^{1}$
}

\author{
W. Z. Yang and K. A. Beauchemin ${ }^{2}$ \\ Agriculture and Agri-Food Canada, Research Centre, Lethbridge, Alberta, T1J 4B1, Canada
}

\begin{abstract}
Intake of physically effective neutral detergent fiber (peNDF) of dairy cows was altered by adjusting the proportion of forage in the diet and forage particle length, and effects on nutrient intake, site and extent of digestion, microbial $\mathrm{N}$ synthesis, and milk production were measured. The experiment was designed as a triplicated $4 \times 4$ Latin square using 12 lactating dairy cows, with 4 that were ruminally and duodenally cannulated, 4 that were ruminally cannulated, and 4 that were intact. Thus, the site and extent of digestion, and microbial $\mathrm{N}$ synthesis were measured in a single $4 \times 4$ Latin square. Treatments were arranged in a $2 \times 2$ factorial design; 2 forage particle lengths (FPL) of alfalfa silage (short and long) were combined with low (35:65) and high (60:40) forage:concentrate (F:C) ratios (dry matter basis). Dietary peNDF content was determined from the sum of the proportion (dry matter basis) of dietary dry matter retained either on the 2 screens (8- and 19$\mathrm{mm}$ ) or on the 3 screens (1.18-, 8-, and 19-mm) of the Penn State Particle Separator multiplied by the neutral detergent fiber content of the diet. An increased F:C ratio reduced intakes of dry matter and starch by 9 and $46 \%$, respectively, but increased intake of fiber from forage sources by 53\%. Digestibility of dry matter in the total tract was not affected, whereas total digestion of fiber and $\mathrm{N}$ was improved by increasing the $\mathrm{F}$ :C ratio. Improved total fiber digestion resulted from higher ruminal digestion, which was partially due to a shift in starch digestion from the rumen to the intestine with the increased F:C ratio. Actual milk yield was decreased but production of $4 \%$ fat-corrected milk was similar between the low and high F:C diets because of increased milk fat content. Increased FPL increased intake of peNDF, especially when the high F:C diet was fed. However, nutrient intakes, $\mathrm{N}$ metabolism in the digestive tract, and milk production were not affected. Digestibil-
\end{abstract}

Received December 5, 2006.

Accepted March 12, 2007.

${ }^{1}$ Contribution number 38706074 .

${ }^{2}$ Corresponding author: beauchemink@agr.gc.ca ity of neutral detergent fiber in the total tract was increased because of improved fiber digestion in the rumen with increased FPL. These results indicate that feeding dairy cows a low F:C diet is beneficial in terms of increasing feed intake, microbial $\mathrm{N}$ synthesis, and milk production. However, low F:C diets do not maximize feed digestion and production efficiency because of the effects of subacute ruminal acidosis. Increased FPL improves fiber utilization with minimal effects on the digestion of other nutrients and milk production. Increasing dietary peNDF, through an increased proportion of forage or increased FPL, improves fiber digestion because of improved rumen function.

Key words: physically effective neutral detergent fiber, digestion, microbial nitrogen synthesis, dairy cow

\section{INTRODUCTION}

The rumen environment and associated microbial populations are designed to function optimally within a $\mathrm{pH}$ range of 6.2 to 7.2 . However, this range of $\mathrm{pH}$ is rarely observed in high-producing dairy cows because their diets are high in concentrate and low in fiber to encourage maximum milk production. Suboptimal ruminal $\mathrm{pH}$ (e.g., $\mathrm{pH} 5.2$ to 5.8) is referred to as subacute ruminal acidosis (SARA; Owens et al., 1998). The incidence of SARA is a tremendous problem for the dairy industry in terms of lost production efficiency and increased cost of treating sick animals (Nocek, 1997). Subacute ruminal acidosis reduces microbial activity, fiber digestion, and the microbial AA supply.

The concept of physically effective NDF (peNDF) is a means of formulating diets to provide fiber of adequate particle length to reduce SARA. Physically effective NDF reflects the ability of the feed to promote chewing and the salivary secretions needed to buffer the rumen and elevate ruminal $\mathrm{pH}$ (Mertens, 1997). A number of studies have recently shown that increased intake of peNDF increases chewing activity and ruminal $\mathrm{pH}$ (Krause et al., 2002b; Beauchemin et al., 2003), improves total digestibility (Kononoff and Heinrichs, 2003a; Yansari et al., 2004; Yang and Beauchemin, 2005), and increases milk fat content (Yang et al., 2001; Kononoff and Heinrichs, 2003a). However, other stud- 
ies have demonstrated either no effects or negative effects of peNDF on ruminal pH (Fernandez et al., 2004; Beauchemin and Yang, 2005), digestibility, and milk composition (Krause et al., 2002a; Kononoff and Heinrichs, 2003b). Beauchemin and Yang (2005) concluded that the variable effects of dietary peNDF content on rumen function, digestion, and productivity of dairy cows are because peNDF content of diets can be increased by increasing the forage proportion of the diet or by increasing the particle length of forages. An increased forage proportion would affect intake of fermentable OM as well as intake of fiber, which could have a significant impact on peNDF requirements. Little information is available documenting the influence of ruminally fermentable carbohydrates on the effects of dietary peNDF levels.

The objectives of the present study were to determine the effects of, and interactions between, level of ruminally fermentable carbohydrate and dietary peNDF content on feed intake, site and extent of digestion, microbial $\mathrm{N}$ synthesis, and milk yield and composition of lactating dairy cows. Dietary peNDF content was varied by adjusting the proportion of forage in the diet and the particle length of silage. Adjusting the proportion of forage in the diet also varied the intake of ruminally fermentable carbohydrate. The effects on chewing activity, ruminal $\mathrm{pH}$, and fermentation were also measured but will be reported separately.

\section{MATERIALS AND METHODS}

\section{Alfalfa Silage}

Second-cut, wilted alfalfa silage (AS) was harvested at the early bloom stage of maturity and ensiled in large silo bags (200-tonne capacity) for 2 mo before being used. A forage harvester (model 6910, John Deere, West Bend, WI), equipped with a 37-tooth sprocket and 8 knives, was used to obtain silage chopped at a theoretical chop length (TCL) of 7.9 and $19.1 \mathrm{~mm}$ for short and long cut silage, respectively. Two kilograms of each AS (short and long) were obtained weekly and immediately subdivided into 3 portions to determine DM content, particle size, and chemical composition, respectively (Table 1). Particle size distribution of the silage was determined using the Penn State Particle Separator (PSPS; Kononoff and Heinrichs, 2003b) equipped with 3 sieves (19, 8, and $1.18 \mathrm{~mm}$ ) and a pan. Dry matter content was determined by oven-drying at $55^{\circ} \mathrm{C}$ for 48 $\mathrm{h}$. The third portion of the samples was composited by experimental period and retained for determination of chemical composition. Fermentation characteristics of the silage were determined commercially by Cumberland Valley Analytical Service Inc. (Maugansville, MD) from one single representative sample from the silo before starting the experiment.

\section{Cows and Diets}

Twelve lactating dairy cows were used, including 4 that were ruminally and duodenally cannulated, 4 that were ruminally cannulated, and 4 that were intact. The experiment was designed as a triplicated $4 \times 4$ Latin square with a $2 \times 2$ factorial arrangement of treatments for measuring intake, total digestibility, milk yield, and milk composition. However, site of digestion and ruminal microbial production were measured with a single $4 \times 4$ Latin square. The ruminal cannulas measured 10 $\mathrm{cm}$ in diameter and were constructed of soft plastic (Bar Diamond, Parma, ID). Duodenal cannulas were Tshaped and were placed proximal to the common bile and pancreatic duct, approximately $10 \mathrm{~cm}$ distal to the pylorus. Cows were housed in individual tie stalls and offered a TMR 3 times daily at 0600, 1500, and $1800 \mathrm{~h}$ for ad libitum intake. Cows averaged $622 \pm 65 \mathrm{~kg}$ of BW and $63 \pm 13$ DIM and were cared for according to the Canadian Council on Animal Care Guidelines (Ottawa, Ontario, Canada).

Cows were offered 1 of 4 diets consisting of the short and long AS, combined with low (35:65) and high (60:40) forage:concentrate (F:C) ratios (DM basis; Table 2). Thus, intake of peNDF was increased by increasing forage particle length (FPL) and proportion of forage in the diet. Contents of peNDF ranged from 9.6 to $19.8 \%$ or from 28.6 to $34.0 \%$ for peNDF estimated with 2 sieves (Lammers et al., 1996) or with 3 sieves (Kononoff et al., 2003), respectively (Table 3). The diets were formulated using the NRC (2001) model to supply sufficient energy and $\mathrm{N}$ for a $650-\mathrm{kg}$ cow to produce $35 \mathrm{~kg} / \mathrm{d}$ of milk containing $3.5 \%$ fat and $3.2 \%$ protein.

Each period consisted of $11 \mathrm{~d}$ of adaptation to diets and $10 \mathrm{~d}$ of experimental measurements. Feed offered and orts were measured and recorded daily during the last $10 \mathrm{~d}$ of the period to calculate feed intake. Feed samples including the AS and TMR were collected once weekly, and orts were collected daily and composited weekly for particle length and DM determination. Samples were then composited by period, dried in an oven at $55^{\circ} \mathrm{C}$ for $48 \mathrm{~h}$, and ground through a $1-\mathrm{mm}$ diameter screen (standard model 4, Arthur H. Thomas Co., Philadelphia, PA) for analysis of OM, NDF, ADF, starch, and CP. Milk production was recorded daily, a.m. and p.m., and was sampled on 5 consecutive days during the last $10 \mathrm{~d}$ of the period for milk fat, $\mathrm{CP}$, and lactose determination using an infrared analyzer (MilkOScan 605, Foss Electric, Hillerød, Denmark). 
Table 1. Chemical composition and particle size distribution of alfalfa silage measured using the Penn State Particle Separator

\begin{tabular}{|c|c|c|c|c|}
\hline \multirow[b]{2}{*}{ Item } & \multicolumn{2}{|c|}{ Alfalfa silage $^{1}$} & \multirow[b]{2}{*}{$\mathrm{SE}$} & \multirow[b]{2}{*}{$P<$} \\
\hline & Short cut & Long cut & & \\
\hline \multicolumn{5}{|l|}{ Chemical composition } \\
\hline $\mathrm{DM}, \%$ & 54.9 & 51.1 & 1.1 & 0.01 \\
\hline $\mathrm{OM}, \%$ of $\mathrm{DM}$ & 89.3 & 89.3 & 0.2 & NS \\
\hline $\mathrm{NDF}, \%$ of DM & 44.7 & 46.2 & 0.5 & 0.03 \\
\hline $\mathrm{ADF}, \%$ of $\mathrm{DM}$ & 37.1 & 35.9 & 0.6 & 0.01 \\
\hline $\mathrm{N}, \%$ of $\mathrm{DM}$ & 3.38 & 3.40 & 0.04 & NS \\
\hline \multicolumn{5}{|l|}{ Physical determination ${ }^{2}$} \\
\hline \multicolumn{5}{|l|}{ DM retained on sieves, $\%$} \\
\hline $19.0 \mathrm{~mm}$ & 12.8 & 23.6 & 1.4 & 0.01 \\
\hline $8.0 \mathrm{~mm}$ & 40.6 & 48.8 & 0.8 & 0.01 \\
\hline $1.18 \mathrm{~mm}$ & 42.1 & 23.2 & 1.0 & 0.01 \\
\hline Pan & 4.6 & 4.4 & 0.2 & NS \\
\hline $\operatorname{pef}_{8.0}$ & 53.3 & 72.4 & 1.2 & 0.01 \\
\hline pef $_{118}$ & 95.4 & 95.6 & 0.2 & NS \\
\hline peNDF $_{8.0}, \%$ of DM & 23.9 & 33.5 & 0.6 & 0.01 \\
\hline peNDF $_{1.18}, \%$ of DM & 42.7 & 44.2 & 0.5 & 0.03 \\
\hline \multicolumn{5}{|l|}{ Fermentation $^{3}$} \\
\hline $\mathrm{pH}$ & 4.90 & 4.74 & - & - \\
\hline Acetic acid, \% of DM & 1.49 & 1.90 & - & - \\
\hline Propionic acid, \% of DM & $<0.01$ & $<0.01$ & - & - \\
\hline Butyric acid, $\%$ of DM & $<0.01$ & $<0.01$ & - & - \\
\hline \multicolumn{5}{|l|}{ Lactic acid } \\
\hline$\%$ of $\mathrm{DM}$ & 4.7 & 7.4 & - & - \\
\hline$\%$ total acid & 75.8 & 79.6 & - & - \\
\hline Ammonia, $\%$ of $\mathrm{DM}$ & 2.2 & 2.0 & - & - \\
\hline
\end{tabular}

\footnotetext{
${ }^{1}$ Alfalfa forage was harvested at a theoretical chop length of 19.1 or $7.9 \mathrm{~mm}$ for long or short cut silages, respectively.

${ }^{2}$ Particle size distribution of alfalfa silage was measured using the Penn State Particle Separator (Kononoff et al., 2003); pef $_{8.0}$ and pef $_{1.18}=$ physical effectiveness factor determined as the proportion of particles retained on 2 sieves (Lammers et al., 1996) and on 3 sieves (Kononoff et al., 2003), respectively; peNDF s.0 $_{8.0}$ and peNDF $_{1.18}=$ physically effective NDF determined as NDF content of alfalfa silage multiplied by pef ${ }_{8.0}$ and pef $_{1.18}$, respectively.

${ }^{3}$ Fermentation parameters were determined by Cumberland Valley Analytical Service, Inc. (Maugamsville, MD) with a single representative sample.
}

\section{Duodenal Flow and Apparent Digestion}

Apparent digestion of nutrients in the total tract (12 cows), duodenal flow, and digestion at the different sites of the digestive tract (4 duodenally cannulated cows) were determined using $\mathrm{YbCl}_{3}$ (Rhône-Poulenc Inc., Shelton, CT) as a digestive marker. The marker was mixed into the concentrate portion of the diets to supply approximately $1.5 \mathrm{~g}$ of $\mathrm{Yb} / \mathrm{d}$ per cow. Ammonia ${ }^{15} \mathrm{~N}$ $\left(\left[{ }^{15} \mathrm{NH}_{4}\right]_{2} \mathrm{SO}_{4}, 10.6\right.$ atom $\%{ }^{15} \mathrm{~N}$, Isotec, Miamisburg, $\mathrm{OH})$ was used as a ruminal microbial marker. Marker solution was continuously infused into the rumen of the 4 duodenally cannulated cows via ruminal cannulas using an automatic pump (model $60 \mathrm{rpm} / 7524-10$, Masterflex L/S microprocessor pump drive, Masterflex Vernon Hills, IL) during the last $11 \mathrm{~d}$ of the period. The daily amounts infused were $140 \mathrm{mg}$ of ${ }^{15} \mathrm{~N}$ dissolved in $800 \mathrm{~mL}$ of water for each cow. Ruminal samples were collected from the duodenally cannulated cows once daily for $4 \mathrm{~d}$ to prepare a bacterial pellet. Duodenal samples were collected 4 times daily every $6 \mathrm{~h}$, moving ahead $2 \mathrm{~h}$ each day for the last $4 \mathrm{~d}$ of infusion. This schedule provided 12 representative samples of duodenal contents taken at 2-h intervals. A ruminal and a duodenal sample taken before infusion of ${ }^{15} \mathrm{~N}$ from each duodenally cannulated cow during the first period were used to determine the background concentration of ${ }^{15} \mathrm{~N}$ in samples. Fecal samples (approximately $200 \mathrm{~g}$ wet weight) were collected for each cow from the rectum twice daily (a.m. and p.m.) at various times (2-h intervals) during the last $6 \mathrm{~d}$ of the period.

Ruminal samples were processed immediately to separate ruminal bacteria. The samples were squeezed through 4 layers of cheesecloth and the particles obtained by squeezing were blended ( $400 \mathrm{~g}$ of particles plus $400 \mathrm{~mL}$ of $0.9 \% \mathrm{NaCl}$ ) in a Waring blender (Waring Products Division, New Hartford, CT) for 1 min and then squeezed through 4 layers of cheesecloth. Filtrates from both squeezed and strained homogenate were mixed and centrifuged $\left(800 \times g\right.$ for $15 \mathrm{~min}$ at $\left.4^{\circ} \mathrm{C}\right)$ to remove protozoa and feed particles, and the superna- 
Table 2. Ingredients of the TMR (DM basis)

\begin{tabular}{|c|c|c|c|c|}
\hline \multirow[b]{3}{*}{ Ingredient, \% } & \multicolumn{4}{|c|}{ Forage $^{1}$ :concentrate $(\mathrm{F}: \mathrm{C})$} \\
\hline & \multicolumn{2}{|c|}{$35: 65$} & \multicolumn{2}{|c|}{$60: 40$} \\
\hline & Short & Long & Short & Long \\
\hline Alfalfa silage, short cut & 35.7 & - & 59.5 & - \\
\hline Alfalfa silage, long cut & - & 35.7 & - & 59.5 \\
\hline Barley grain, steam-rolled ${ }^{2}$ & 56.1 & 56.1 & 31.1 & 31.1 \\
\hline Corn gluten meal & 3.33 & 3.33 & 3.33 & 3.33 \\
\hline Canola meal (Alberta Gold) ${ }^{3}$ & 1.43 & 1.43 & 1.19 & 1.19 \\
\hline Soy $\mathrm{Pass}^{4}$ & 1.43 & 1.43 & 1.19 & 1.19 \\
\hline Beet molasses & 0.48 & 0.48 & 0.95 & 0.95 \\
\hline Calcium carbonate & 0.24 & 0.24 & 0.24 & 0.24 \\
\hline Dicalcium phosphorus & 0.24 & 0.24 & 0.24 & 0.24 \\
\hline Monosodium phosphate & 0.05 & 0.05 & 0.05 & 0.05 \\
\hline Vitamin-mineral mix $^{5}$ & 0.71 & 0.71 & 0.71 & 0.71 \\
\hline Canola oil & 0.19 & 0.19 & 0.48 & 0.48 \\
\hline Rumen inert fat ${ }^{6}$ & - & - & 0.95 & 0.95 \\
\hline Binding agent $(\mathrm{Aka})^{7}$ & 0.11 & 0.11 & 0.12 & 0.12 \\
\hline Flavoring agent & 0.01 & 0.01 & 0.01 & 0.01 \\
\hline \multicolumn{5}{|c|}{$\begin{array}{l}{ }^{1} \text { Alfalfa forage was harvested at a theoretical chop length of } 19.1 \text { or } 7.9 \mathrm{~mm} \text { for long and short cut silages, } \\
\text { respectively. }\end{array}$} \\
\hline \multicolumn{5}{|c|}{${ }^{2}$ Chemical composition of barley grain (DM basis) was $97.7 \%$ for OM; $20.8 \%$ for NDF; $7.2 \%$ for ADF; and } \\
\hline \multirow{2}{*}{\multicolumn{5}{|c|}{$\begin{array}{l}{ }^{3} \text { A registered trademark for heat-processed canola meal product (Canbra Foods, Lethbridge, Alberta, } \\
\text { Canada). }\end{array}$}} \\
\hline & & & & \\
\hline \multicolumn{5}{|c|}{$\begin{array}{l}{ }^{4} \text { A registered trademark for heat-processed soybean meal product (Borregaard LignoTech, Rothschild, } \\
\text { VI). }\end{array}$} \\
\hline \multirow{3}{*}{\multicolumn{5}{|c|}{$\begin{array}{l}{ }^{5} \mathrm{Contained} 58.8 \% \mathrm{NaCl}, 16.0 \% \text { Dynamate (Pitman Moore, Inc., Mundelein, IL; } 18 \% \mathrm{~K}, 11 \% \mathrm{Mg}, 22 \% \\
\mathrm{~S}, 1,000 \mathrm{mg} \mathrm{Fe} / \mathrm{kg} \text { ), } 2 \% \mathrm{ZnSO}_{4} \cdot \mathrm{H}_{2} \mathrm{O}, 2.4 \% \mathrm{MnSO}_{4} \cdot 4 \mathrm{H}_{2} \mathrm{O}, 0.01 \% \mathrm{CoSO}_{4} \cdot 6 \mathrm{H}_{2} \mathrm{O}, 0.009 \% \mathrm{Na}_{2} \mathrm{SeO}_{3}, 0.012 \% \\
\text { ethylenediamine dihydroiodide, } 0.8 \% \mathrm{CuSO}_{4} \cdot 5 \mathrm{H}_{2} \mathrm{O}, 2,000,000 \mathrm{IU} / \mathrm{kg} \text { of vitamin } \mathrm{A}, 200,000 \mathrm{IU} / \mathrm{kg} \text { of vitamin } \\
\mathrm{D} \text {, and } 2,000 \mathrm{IU} / \mathrm{kg} \text { of vitamin } \mathrm{E} \text {. }\end{array}$}} \\
\hline & & & & \\
\hline & & & & \\
\hline \multicolumn{5}{|c|}{${ }^{6}$ Enertia, ADM Animal Health and Nutrition (Quincy, IL). } \\
\hline${ }^{7}$ Bear River Zeolite of Cana & & & & \\
\hline
\end{tabular}

tant was centrifuged $\left(27,000 \times g\right.$ for $30 \mathrm{~min}$ at $\left.4^{\circ} \mathrm{C}\right)$ to obtain a mixed ruminal bacterial pellet. Bacterial pellets were accumulated by period, freeze-dried, ground using a mortar and pestle, and then further ground to a fine powder using a ball mill (mixer mill MM2000, Retsch, Haan, Germany) for determination of $\mathrm{N}$ content and ${ }^{15} \mathrm{~N}$ enrichment.

Duodenal samples were mixed using an electric drill fitted with a shaft and propeller. Each sample was then split into 3 fractions that were pooled by cow within period and retained for ammonia analysis, DM determination after oven-drying at $55^{\circ} \mathrm{C}$, or chemical analysis after freeze-drying. Fecal samples were immediately subsampled (about $50 \mathrm{~g}$ ), composited across sampling times for each cow and each period, dried at $55^{\circ} \mathrm{C}$, ground to pass a 1-mm sieve (standard model 4, Arthur $\mathrm{H}$. Thomas Co.), and stored for chemical analysis.

\section{Chemical Analyses}

Feed DM was determined by oven-drying at $55^{\circ} \mathrm{C}$ for $48 \mathrm{~h}$. Analytical DM content of the samples was determined by drying at $135^{\circ} \mathrm{C}$ for $3 \mathrm{~h}$ (AOAC, 1990).
Organic matter content was calculated as the difference between DM and ash contents, with ash determined by combustion at $550^{\circ} \mathrm{C}$ overnight. Contents of NDF and $\mathrm{ADF}$ were determined using the methods described by Van Soest et al. (1991), with amylase and sodium sulfite used in the NDF procedure. Starch was determined by enzymatic hydrolysis of $\alpha$-linked glucose polymers as described by Rode et al. (1999). Contents of digestive markers in the duodenal and fecal samples were determined using inductively coupled plasma optical emission spectroscopy according to the AOAC (1990) method modified such that no $\mathrm{CaCl}_{2}$ was used during sample digestion for $\mathrm{Yb}$ analysis. Content of $\mathrm{N}$ in the samples was determined by flash combustion (model 1500, Carlo Erba Instruments, Milan, Italy), and enrichment of ${ }^{15} \mathrm{~N}$ in the rumen bacterial and duodenal samples was analyzed with isotope ratio mass spectrometry (VG Isotech, Middlewich, UK). Particle size distributions of AS and TMR were determined using the PSPS. Physical effectiveness factors (pef) for silage and TMR were calculated as the sum of the proportion of DM retained on

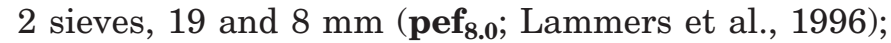
or on 3 sieves, 19, 8, and $1.18 \mathrm{~mm}$ (pef (1.18; $_{\text {; Kononoff et }}$ 
Table 3. Physical and chemical composition of the diets

\begin{tabular}{|c|c|c|c|c|c|c|c|c|}
\hline \multirow[b]{3}{*}{ Item } & \multicolumn{4}{|c|}{ Forage $^{1}$ :concentrate $(\mathrm{F}: \mathrm{C})$} & \multirow[b]{3}{*}{$\mathrm{SE}$} & \multirow{2}{*}{\multicolumn{3}{|c|}{ Effect }} \\
\hline & \multicolumn{2}{|c|}{$35: 65$} & \multicolumn{2}{|c|}{$60: 40$} & & & & \\
\hline & Short & Long & Short & Long & & $\mathrm{F}: \mathrm{C}$ & $\mathrm{F}^{1}$ & $\mathrm{~F}: \mathrm{C}^{*} \mathrm{~F}$ \\
\hline \multicolumn{9}{|l|}{ Physical $^{2}$} \\
\hline \multicolumn{9}{|c|}{ DM retained on screens, $\%$} \\
\hline $19.0 \mathrm{~mm}$ & 3.6 & 7.1 & 7.1 & 13.1 & 0.8 & 0.01 & 0.01 & 0.03 \\
\hline $8.0 \mathrm{~mm}$ & 27.8 & 34.5 & 33.3 & 41.1 & 1.0 & 0.01 & 0.01 & $\mathrm{NS}^{3}$ \\
\hline $1.18 \mathrm{~mm}$ & 63.0 & 52.8 & 52.9 & 39.1 & 0.8 & 0.01 & 0.01 & 0.01 \\
\hline Pan & 5.6 & 5.7 & 6.6 & 6.7 & 0.3 & 0.01 & NS & NS \\
\hline $\operatorname{pef}_{8.0}$ & 31.4 & 41.5 & 40.4 & 54.2 & 0.9 & 0.01 & 0.01 & 0.03 \\
\hline pef $_{1.18}$ & 94.4 & 94.3 & 93.4 & 93.3 & 0.3 & 0.01 & NS & NS \\
\hline peNDF $_{80}, \%$ & 9.6 & 12.7 & 13.9 & 19.8 & 0.6 & 0.01 & 0.01 & 0.03 \\
\hline peNDF $_{1.18}, \%$ & 28.6 & 28.8 & 32.2 & 34.0 & 0.9 & 0.01 & NS & NS \\
\hline \multicolumn{9}{|l|}{ Chemical } \\
\hline $\mathrm{DM}, \%$ & 72.5 & 71.1 & 66.0 & 62.0 & 1.4 & 0.01 & 0.02 & NS \\
\hline $\mathrm{OM}, \%$ of $\mathrm{DM}$ & 93.4 & 93.1 & 91.2 & 90.9 & 0.3 & 0.01 & NS & NS \\
\hline $\mathrm{N}, \%$ of $\mathrm{DM}$ & 3.18 & 3.28 & 3.46 & 3.49 & 0.06 & 0.01 & NS & NS \\
\hline $\mathrm{NDF}, \%$ of DM & 30.3 & 30.6 & 34.5 & 36.4 & 0.9 & 0.01 & NS & NS \\
\hline Forage NDF, $\%$ of DM & 16.0 & 16.5 & 26.6 & 27.5 & 0.2 & 0.01 & 0.01 & NS \\
\hline NDF from forage, $\%$ & 53.0 & 54.0 & 77.2 & 75.6 & 1.9 & 0.01 & NS & NS \\
\hline $\mathrm{ADF}, \%$ of $\mathrm{DM}$ & 20.4 & 21.6 & 26.9 & 27.4 & 0.5 & 0.01 & 0.06 & NS \\
\hline Starch, \% of DM & 30.6 & 30.6 & 17.8 & 17.8 & 0.8 & 0.01 & NS & NS \\
\hline $\mathrm{NE}_{\mathrm{L}}, \mathrm{Mcal} / \mathrm{kg}$ & 1.65 & 1.65 & 1.65 & 1.65 & - & - & - & - \\
\hline
\end{tabular}

\footnotetext{
${ }^{1}$ Alfalfa forage was harvested at a theoretical chop length of 19.1 and $7.9 \mathrm{~mm}$ for long and short cut silages, respectively.

${ }^{2}$ Particle size distribution of TMR was measured using the Penn State Particle Separator (Kononoff et al., 2003); pef $_{8.0}$ and pef $_{1.18}=$ physical effectiveness factor determined as the proportion of particles retained on 2 sieves (Lammers et al., 1996) and on 3 sieves (Kononoff et al., 2003), respectively; peNDF 8.0 and peNDF $_{1.18}=$ physically effective NDF determined as NDF content of TMR multiplied by pef $f_{8.0}$ and pef $f_{1.18}$, respectively.

${ }^{3} \mathrm{NS}=P>0.15$.
}

al., 2003). The peNDF content of the AS and TMR was calculated by multiplying NDF content of the feed (DM basis) by pef p.0 $_{8.0}\left(\mathbf{p e N D F}_{\mathbf{8 . 0}}\right)$ and pef $_{1.18}\left(\mathbf{p e N D F}_{\mathbf{1 . 1 8}}\right)$.

\section{Calculations and Statistical Analyses}

Flows of DM to the duodenum and DM excreted in feces were calculated by dividing $\mathrm{Yb}$ actually consumed (i.e., after adjustment for $\mathrm{Yb}$ concentration of orts, grams of $\mathrm{Yb}$ per day) by $\mathrm{Yb}$ concentration (grams of $\mathrm{Yb}$ per kilogram of DM) in the duodenal digesta or feces, respectively. Flows of other nutrients to the duodenum or feces were calculated by multiplying DM flow by their concentration in duodenal or fecal DM. Ruminal microbial $\mathrm{N}$ synthesis for each cow was estimated by the ratio of ${ }^{15} \mathrm{~N}$ flow at the duodenum to ${ }^{15} \mathrm{~N}$ concentration of mixed ruminal bacteria.

Data were analyzed using the mixed model procedure of SAS (PROC MIXED, SAS Institute, 1996) to account for effects of square, period within square, cow within square, treatments (FPL and F:C), and the interaction between FPL and F:C. Treatments were considered a fixed effect; square, period within square, and cow within square were considered random effects. For variables of site of digestion and microbial $\mathrm{N}$ synthesis, data from a single square were analyzed. In that case, the mixed model accounted for effects of period, cow, treatments (FPL and F:C), and the interaction between FPL and F:C. Treatments were considered a fixed effect; period and cow were considered random effects. Data for particle distribution, pef, and peNDF of forages and diets were averaged by period and analyzed by including particle length as a fixed effect and period as a random effect. The estimation method was the REML, and the degrees of freedom method was Kenward-Rogers. Effects of the treatments were declared significant at $P<0.05$ unless otherwise noted, and trends were discussed at $P<0.15$.

\section{RESULTS AND DISCUSSION}

\section{Particle Size Distribution and peNDF of Feeds}

The nutrient composition and particle size distribution of short and long cut AS are presented in Table 1. Although there were some statistically significant differences between the nutrient profiles of these 2 forages, the differences in $\mathrm{NDF}(1.5 \%)$ and in $\mathrm{ADF}(1.2 \%)$ were small. Thus, any influence of silage chemical composition on digestion in the rumen and in the intestine 
was expected to be relatively minor. As expected, the proportion of particles retained on the 8- and 19-mm sieves increased as the TCL of AS increased from 7.9 to $19.1 \mathrm{~mm}$, and as a result, pef $_{8.0}$ and peNDF ${ }_{8.0}$ were increased by up to $40 \%$. However, increases in pef $f_{1.18}$ and peNDF 1.18 were minimal because the increased proportion of material on the $19-\mathrm{mm}$ sieve was offset by the decrease in material on the 1.18-mm sieve with increasing chop length of AS. Thus, measuring pef and peNDF using 2 sieves was more sensitive to changes in the proportion of forage and particle length of forage than were measurements using 3 sieves.

Fermentation characteristics of the AS were not analyzed statistically because of a single determination for each silage (Table 1). However, the differences between the 2 silages in $\mathrm{pH}$ and concentration of organic acids were small; thus, their impact on rumen fermentation was expected to be minimal. In support of this expectation, mean ruminal $\mathrm{pH}$ of cows fed long cut AS was higher than for cows fed short cut AS, even though the long cut silage had a slightly lower $\mathrm{pH}$ and higher lactic acid content (Yang and Beauchemin, 2007). From this result, it can be surmised that the comparisons among diets containing short or long AS mainly reflected the differences in particle length of the silages.

The diets with low F:C were different in chemical composition from the diets with high $\mathrm{F}: \mathrm{C}$ as expected (Table 3). In particular, fiber content was higher and contents of DM and starch were lower for the high F:C ratio diet. Differences in chemical composition between the diets containing short and long AS were small, although there were differences in $\mathrm{DM}, \mathrm{ADF}$, and forage NDF content because of the small differences between the 2 silages (Table 1 ).

Increasing the $\mathrm{F}: \mathrm{C}$ ratio and FPL both increased dietary peNDF $_{8.0}$, but the effects of FPL were greater when the F:C ratio was high, indicating that particle length of forages has a greater impact on the physical effectiveness of TMR when it contains a higher proportion of forage.

The pef $_{1.18}$ and peNDF 1.18 were increased with the increased F:C ratio, but they were not affected by FPL. The lack of effect of FPL on these measures of peNDF confirms our previous conclusion that when used with the PSPS, the 1.18-mm sieve does not adequately measure the pef of silage-based diets (Yang and Beauchemin, 2006b). This conclusion is also supported by the study of Kononoff and Heinrichs (2003a) in which dietary peNDF ${ }_{1.18}$ contents were similar for diets even though the proportion of corn silage in the diets varied from 45 to $57 \%$.

\section{Intake and Apparent Digestion in the Total Tract}

Intakes of DM and OM, expressed as kilograms per day or percentage of BW, were reduced by approxi- mately $10 \%$ with increased F:C ratio (Table 4). Lower DMI with high-forage diets is well documented (Kalscheur et al., 1997; Soita et al., 2005) and is thought to be due to the "rumen filling" effect of forage. The variation in intakes of starch, NDF, and ADF with changes in the $\mathrm{F}: \mathrm{C}$ ratio reflect both $\mathrm{DMI}$ and composition of the diet consumed. Dramatically increased intake $(42 \%)$ of peNDF $_{8.0}$ with increased $\mathrm{F}: \mathrm{C}$ ratio was associated with the increased intake of forages. In contrast, higher forage intake only increased the peNDF ${ }_{1.18}$ intake by $6 \%$, because pef 1.18 was relatively unresponsive to changes in FPL. Intake of starch was 54\% lower with the high F:C diet because of its lower starch content. Intake of $\mathrm{N}$ was not affected by $\mathrm{F}: \mathrm{C}$ ratio because a decrease in DMI was compensated for by an increase in $\mathrm{N}$ content as $\mathrm{F}: \mathrm{C}$ ratio increased.

Forage particle length had no effect on intakes of DM or other nutrients other than intakes of peNDF $_{8.0}$ and digestible NDF, which were higher for long AS than for short AS diets. This finding is consistent with other studies that used AS-based diets containing more than $40 \%$ concentrate (Krause et al., 2002a; Yang et al., 2002). In contrast, other studies with high-forage diets (100\% barley silage; Soita et al., 2002) or very long FPL (TCL = $22.3 \mathrm{~mm}$; Kononoff and Heinrichs, 2003b) reported increased DMI with reduced FPL, presumably because of the reduction in "rumen fill." There was an interaction between FPL and F:C ratio for intake of dietary peNDF ${ }_{8.0}$; the increase with increasing FPL was greater for the high $\mathrm{F}: \mathrm{C}$ diet because of its higher forage content.

Overall, there was no interaction between $\mathrm{F}: \mathrm{C}$ ratio and FPL on digestibility in the total tract except for starch (Table 4). Digestibility of starch was increased with long AS for low F:C, and it was not changed with increasing FPL for high F:C diets. Increased F:C ratio did not affect the digestibility of DM or OM in the total tract but increased the digestibilities of NDF, ADF, and $\mathrm{N}$ by 28,34 , and $7 \%$, respectively. The higher DMI of the low F:C diet, combined with its higher NSC fermentability, compared with the lower DMI of the high F:C diet, combined with high fiber digestibility, may explain the similar total digestibility of DM or OM for these 2 diets. These results are in agreement with Moorby et al. (2006), who reported that total digestibility of DM was similar but that of NDF increased from 60 to $64 \%$ when the F:C ratio increased from 35:65 to 65:35 for a ryegrass silage-based diet. In contrast, Llamas-Lamas and Combs (1991) reported that digestibilities of DM and NDF declined slightly with increased F:C ratio (from 56:44 to 71:29, and then to 86:14) for AS-based diets. Yang et al. (2001) also reported that increasing the F:C ratio from 35:65 to 55:45 reduced fiber digestion from 47.9 to $44.5 \%$ when diets 
Table 4. Effects of forage-to-concentrate ratio and forage particle size on intake and digestibility of nutrients in the total tract of lactating dairy cows $(\mathrm{n}=12)$

\begin{tabular}{|c|c|c|c|c|c|c|c|c|}
\hline \multirow[b]{3}{*}{ Item } & \multicolumn{4}{|c|}{ Forage $^{1}$ :concentrate $(\mathrm{F}: \mathrm{C})$} & \multirow[b]{3}{*}{$\mathrm{SE}$} & \multirow{2}{*}{\multicolumn{3}{|c|}{ Effect }} \\
\hline & \multicolumn{2}{|c|}{$35: 65$} & \multicolumn{2}{|c|}{$60: 40$} & & & & \\
\hline & Short & Long & Short & Long & & $\mathrm{F}: \mathrm{C}$ & $\mathrm{F}^{1}$ & $\mathrm{~F}: \mathrm{C} \times \mathrm{F}$ \\
\hline \multicolumn{9}{|l|}{ Intake } \\
\hline $\mathrm{DM}, \mathrm{kg} / \mathrm{d}$ & 24.0 & 23.7 & 21.7 & 21.8 & 1.2 & 0.01 & $\mathrm{NS}^{2}$ & NS \\
\hline $\mathrm{DM}, \%$ of $\mathrm{BW}$ & 3.79 & 3.77 & 3.51 & 3.48 & 0.11 & 0.01 & NS & NS \\
\hline $\mathrm{OM}, \mathrm{kg} / \mathrm{d}$ & 22.4 & 22.1 & 19.9 & 19.9 & 1.8 & 0.01 & NS & NS \\
\hline $\mathrm{NDF}, \mathrm{kg} / \mathrm{d}$ & 7.1 & 7.1 & 7.3 & 7.8 & 0.7 & 0.02 & NS & 0.13 \\
\hline $\begin{array}{l}\text { Forage NDF, kg/d } \\
\text { peNDF },{ }^{3} \mathrm{~kg} / \mathrm{d}\end{array}$ & 3.8 & 3.9 & 5.8 & 6.0 & 0.4 & 0.01 & NS & NS \\
\hline $\operatorname{peNDF}_{8.0}, \%$ & 2.1 & 2.7 & 2.7 & 4.1 & 0.3 & 0.01 & 0.01 & 0.02 \\
\hline $\operatorname{peNDF}_{1.18}, \%$ & 6.7 & 6.6 & 6.8 & 7.3 & 0.6 & 0.07 & NS & 0.12 \\
\hline $\mathrm{ADF}, \mathrm{kg} / \mathrm{d}$ & 4.8 & 5.0 & 5.7 & 5.9 & 0.5 & 0.01 & NS & NS \\
\hline Starch, kg/d & 7.2 & 7.0 & 3.8 & 3.8 & 0.5 & 0.01 & NS & NS \\
\hline $\mathrm{N}, \mathrm{g} / \mathrm{d}$ & 765.7 & 778.3 & 753.9 & 766.8 & 65.3 & NS & NS & NS \\
\hline $\mathrm{BW}, \mathrm{kg}$ & 626 & 629 & 618 & 623 & 39 & NS & NS & NS \\
\hline \multicolumn{9}{|c|}{ Digestibility, $\%$ of intake } \\
\hline $\mathrm{DM}$ & 58.7 & 60.4 & 59.7 & 61.5 & 2.1 & NS & NS & NS \\
\hline $\mathrm{OM}$ & 60.4 & 62.1 & 61.3 & 63.1 & 2.0 & NS & NS & NS \\
\hline $\mathrm{NDF}$ & 30.6 & 35.3 & 38.5 & 45.7 & 3.4 & 0.01 & 0.05 & NS \\
\hline $\mathrm{ADF}$ & 27.1 & 36.4 & 39.6 & 45.7 & 3.4 & 0.01 & 0.02 & NS \\
\hline Starch & 91.1 & 93.3 & 94.7 & 94.0 & 1.0 & 0.01 & NS & 0.03 \\
\hline $\mathrm{N}$ & 57.6 & 59.9 & 61.5 & 64.4 & 2.1 & 0.01 & 0.08 & NS \\
\hline
\end{tabular}

${ }^{1}$ Alfalfa forage was harvested at a theoretical chop length of 19.1 and $7.9 \mathrm{~mm}$ for long and short cut silages, respectively.

${ }^{2} \mathrm{NS}=P>0.15$

${ }^{3} \mathrm{peNDF}_{8.0}$ and $\mathrm{peNDF}_{1.18}=$ physically effective NDF determined as NDF content of TMR multiplied by pef $_{8.0}$ and pef $_{1.18}$, respectively (Table 3 ).

contained both AS and barley silage. Total tract digestion of fiber reflects digestion in the rumen, although there can be some postruminal compensation for low ruminal digestion (Yang et al., 2001). Ruminal fiber digestion is a function of the proportion of fiber that is potentially digestible, the rate of fiber digestion in the rumen, and the rate of fiber passage from the rumen (Allen and Mertens, 1988). Therefore, the effects of F:C ratio on total tract fiber digestibility are expected to vary with the composition of the fiber and the concentrate level, which affect ruminal digestion.

As observed for increased F:C ratio, increased FPL improved total digestion of $\mathrm{NDF}, \mathrm{ADF}$, and $\mathrm{N}$ without affecting digestion of DM and OM. This finding indicates that both means of increasing the peNDF intake of cows have similar effects on nutrient digestion in the total tract (Table 4). Thus, the present study indicates that peNDF is a good indication of total tract fiber digestion. This finding is consistent with several studies that used alfalfa-based diets (Yang et al., 2002; Yansari et al., 2004) but is in contrast to others (Krause et al., 2002a; Kononoff and Heinrichs, 2003b). The apparent discrepancy among studies is likely related to whether increased F:C ratio or increased FPL increases peNDF intake in a manner that improves rumen function, and thus fiber digestion (Yansari et al., 2004).

\section{Site and Extent of Digestion}

Data for the site and extent of nutrient digestion were obtained from a single $4 \times 4$ Latin square using 4 lactating dairy cows fitted with ruminal and duodenal cannulas. Intakes of DM (range of 18.0 to $20.9 \mathrm{~kg} / \mathrm{d}$ ) as well as of other nutrients (Table 5) were lower than the averages of all cows (Table 4) because cows of smaller frame size $(\mathrm{BW}=575 \mathrm{~kg})$ were used in this group. However, the difference in DMI between these 2 groups was smaller when expressed as a percentage of BW $(<7 \%)$ than when expressed as kilograms per day (14\%). Similar to the observations based on all cows, intakes of DM and other nutrients except for NDF were reduced with increased F:C ratio. Duodenal flows of total OM, microbial OM, starch, and the amount of OM truly fermented in the rumen were higher by $13,15,55$, and $15 \%$, respectively, for low F:C than for high F:C diets. More microbial OM flow at the duodenum was consistent with a higher amount of ruminal fermented OM with the low F:C diet. Ruminal microbial production mainly depends on the amount of OM digested in the rumen. The effects of FPL on intakes and duodenal nutrient flows were not significant. The lack of effect of FPL on intake is consistent with the overall observation (Table 4). There was no interaction between F:C ratio and FPL. 
Table 5. Effects of forage-to-concentrate ratio and forage particle size on intake, duodenal flow, and site and extent of digestion of nutrients in lactating dairy cows $(n=4)$

\begin{tabular}{|c|c|c|c|c|c|c|c|c|}
\hline \multirow[b]{3}{*}{ Item } & \multicolumn{4}{|c|}{ Forage $^{1}$ :concentrate $(\mathrm{F}: \mathrm{C})$} & \multirow[b]{3}{*}{ SE } & \multirow{2}{*}{\multicolumn{3}{|c|}{ Effect }} \\
\hline & \multicolumn{2}{|c|}{$35: 65$} & \multicolumn{2}{|c|}{$60: 40$} & & & & \\
\hline & Short & Long & Short & Long & & $\mathrm{F}: \mathrm{C}$ & $\mathrm{F}^{1}$ & $\mathrm{~F}: \mathrm{C} \times \mathrm{F}$ \\
\hline \multicolumn{9}{|l|}{ Intake, $\mathrm{kg} / \mathrm{d}$} \\
\hline $\mathrm{DM}, \mathrm{kg} / \mathrm{d}$ & 20.3 & 20.9 & 18.6 & 18.0 & 0.7 & 0.01 & $\mathrm{NS}^{2}$ & NS \\
\hline $\mathrm{DM}, \%$ of $\mathrm{BW}$ & 3.50 & 3.61 & 3.27 & 3.17 & 0.16 & 0.01 & NS & NS \\
\hline $\mathrm{OM}$ & 19.0 & 19.5 & 17.0 & 16.4 & 0.7 & 0.01 & NS & NS \\
\hline $\mathrm{NDF}$ & 5.9 & 6.2 & 6.2 & 6.5 & 0.3 & NS & NS & NS \\
\hline Starch & 6.0 & 6.2 & 3.2 & 3.1 & 0.2 & 0.01 & NS & NS \\
\hline BW, kg & 581 & 580 & 568 & 569 & 24 & NS & NS & NS \\
\hline \multirow{2}{*}{\multicolumn{9}{|c|}{$\begin{array}{l}\text { Duodenal flow, kg/d } \\
\text { OM }\end{array}$}} \\
\hline \multicolumn{6}{|l|}{$\mathrm{OM}$} & & & \\
\hline Total & 13.9 & 13.6 & 12.2 & 11.7 & 1.0 & 0.01 & NS & NS \\
\hline Microbial & 3.7 & 4.1 & 3.3 & 3.3 & 0.5 & 0.03 & NS & NS \\
\hline $\mathrm{NDF}$ & 4.5 & 4.2 & 4.3 & 3.8 & 0.3 & $\mathrm{NS}$ & NS & NS \\
\hline Starch & 1.7 & 1.7 & 1.2 & 1.0 & 0.1 & 0.01 & NS & NS \\
\hline $\mathrm{RFOM}^{3} \mathrm{~kg} / \mathrm{d}$ & 8.9 & 10.0 & 8.0 & 8.0 & 0.5 & 0.02 & NS & NS \\
\hline \multicolumn{9}{|c|}{ Digestibility, $\%$ of intake } \\
\hline \multicolumn{9}{|c|}{ Rumen } \\
\hline DM (truly) & 46.6 & 51.3 & 47.6 & 49.2 & 2.7 & NS & 0.13 & NS \\
\hline OM (truly) & 48.3 & 53.1 & 48.6 & 50.3 & 2.6 & NS & 0.12 & NS \\
\hline $\mathrm{NDF}$ & 23.3 & 31.5 & 31.1 & 40.5 & 4.8 & 0.02 & 0.02 & NS \\
\hline Starch & 71.9 & 71.9 & 62.6 & 68.6 & 3.0 & 0.06 & NS & NS \\
\hline \multicolumn{9}{|l|}{ Intestine } \\
\hline $\mathrm{DM}$ & 38.1 & 37.1 & 36.5 & 37.6 & 4.3 & NS & NS & NS \\
\hline $\mathrm{OM}$ & 34.6 & 32.4 & 32.9 & 34.2 & 3.9 & NS & NS & NS \\
\hline $\mathrm{NDF}$ & 7.6 & 2.5 & 7.6 & 5.1 & 5.7 & NS & NS & NS \\
\hline Starch & 19.1 & 23.1 & 33.0 & 24.9 & 3.7 & 0.05 & NS & 0.11 \\
\hline \multicolumn{9}{|l|}{ Total } \\
\hline $\mathrm{DM}$ & 59.8 & 61.0 & 59.7 & 61.9 & 3.3 & NS & NS & NS \\
\hline $\mathrm{OM}$ & 61.4 & 62.5 & 61.3 & 63.4 & 3.2 & NS & NS & NS \\
\hline $\mathrm{NDF}$ & 31.0 & 34.0 & 38.7 & 45.6 & 4.8 & 0.03 & 0.15 & NS \\
\hline Starch & 91.1 & 94.9 & 95.6 & 93.5 & 1.7 & NS & NS & 0.10 \\
\hline
\end{tabular}

Digestibilities (\% of intake) of DM and OM in the rumen and in the intestine were not affected by $\mathrm{F}: \mathrm{C}$ ratio (Table 5). Consequently, digestibilities of DM and $\mathrm{OM}$ in the total tract were similar between low and high F:C ratio diets, which was consistent with the overall result based on the 12 cows (Table 4). Improved NDF digestibility in the total tract with increasing F:C ratio was due to higher ruminal rather than intestinal NDF digestion. The present results are in agreement with the findings of Moorby et al. (2006) that ruminal digestibility of NDF was linearly increased with increasing $\mathrm{F}: \mathrm{C}$ ratio. Lower NDF digestion in the rumen of cows consuming the low $\mathrm{F}: \mathrm{C}$ ratio diet likely resulted from the low ruminal $\mathrm{pH}$ of cows fed this diet (Yang and Beauchemin, 2007). In addition, $\mathrm{F}: \mathrm{C}$ ratio affects the relative proportion of NDF from barley grain and AS. Ruminal digestibility of barley NDF is expected to be lower than that of NDF from AS because of a shorter ruminal retention time of small particles such as barley hulls. Starch digestibility, both in the rumen and in the intestine, was affected by F:C ratio, but the effect of F:C ratio on starch digestion in the total tract was minimal. Lower starch digestion in the rumen for the high $\mathrm{F}$ :C diet was totally compensated for by higher intestinal digestion. The present results confirm our previous study (Yang et al., 2001), in which starch digestibility in the rumen was reduced by $18 \%$ but starch digestibility in the intestine increased by $27 \%$ with increased F:C ratio of the diet. Thus, increasing the proportion of forage in the diet decreases the starch content of the diet and shifts starch digestion from the rumen to the intestine, which are important mechanisms in terms of improving rumen function.

Increased FPL in the diet increased ruminal digestibility by 18 percentage units for NDF and by 6 percentage units for $\mathrm{DM}(P<0.13)$ and $\mathrm{OM}(P<0.12)$. However, there were no effects of dietary FPL on intestinal digestibility. Hence, increased NDF digestion in the total 
Table 6. Effects of forage-to-concentrate ratio and forage particle size on intake and metabolism of $\mathrm{N}$ in the digestive tract of lactating dairy cows $(n=4)$

\begin{tabular}{|c|c|c|c|c|c|c|c|c|}
\hline \multirow[b]{3}{*}{ Item } & \multicolumn{4}{|c|}{ Forage $^{1}$ :concentrate (F:C) } & \multirow[b]{3}{*}{$\mathrm{SE}$} & \multirow{2}{*}{\multicolumn{3}{|c|}{ Effect }} \\
\hline & \multicolumn{2}{|c|}{$35: 65$} & \multicolumn{2}{|c|}{$60: 40$} & & & & \\
\hline & Short & Long & Short & Long & & $\mathrm{F}: \mathrm{C}$ & $\mathrm{F}^{1}$ & $\mathrm{~F}: \mathrm{C} \times \mathrm{F}$ \\
\hline Intake, g/d & 649.1 & 686.0 & 644.0 & 634.1 & 17.4 & 0.05 & $\mathrm{NS}^{2}$ & 0.10 \\
\hline \multicolumn{9}{|l|}{ Flow to duodenum } \\
\hline $\mathrm{g} / \mathrm{d}$ & 697.4 & 761.2 & 624.0 & 609.2 & 61.9 & 0.01 & NS & NS \\
\hline$\%$ of intake & 107.9 & 111.4 & 96.8 & 95.7 & 9.4 & 0.06 & NS & NS \\
\hline \multicolumn{9}{|l|}{ NAN } \\
\hline $\mathrm{g} / \mathrm{d}$ & 679.7 & 740.1 & 607.3 & 592.9 & 59.3 & 0.01 & NS & NS \\
\hline$\%$ of intake & 105.1 & 108.4 & 94.2 & 93.1 & 9.0 & 0.06 & NS & NS \\
\hline \multicolumn{9}{|l|}{ Feed + endogenous } \\
\hline $\mathrm{g} / \mathrm{d}$ & 322.4 & 334.3 & 297.3 & 284.7 & 23.3 & 0.03 & NS & NS \\
\hline$\%$ of intake & 49.7 & 48.8 & 46.1 & 44.8 & 3.3 & NS & NS & NS \\
\hline \multicolumn{9}{|l|}{ Microbial } \\
\hline $\mathrm{g} / \mathrm{d}$ & 357.2 & 405.6 & 310.1 & 308.2 & 45.2 & 0.04 & NS & NS \\
\hline$\%$ of intake & 55.4 & 59.5 & 48.1 & 48.4 & 7.0 & 0.08 & NS & NS \\
\hline $\mathrm{g} / \mathrm{kg}$ of $\mathrm{RFOM}^{3}$ & 39.4 & 39.8 & 38.8 & 37.7 & 7.0 & NS & NS & NS \\
\hline \multicolumn{9}{|l|}{ Digestibility } \\
\hline Ruminal (truly), \% & 50.3 & 51.2 & 53.9 & 55.2 & 3.3 & NS & NS & NS \\
\hline \multicolumn{9}{|l|}{ Postruminal } \\
\hline$\%$ of intake & 66.0 & 71.4 & 57.4 & 61.0 & 8.0 & 0.13 & NS & NS \\
\hline$\%$ of flow to duodenum & 59.7 & 61.8 & 58.5 & 62.6 & 3.3 & NS & $\mathrm{NS}$ & NS \\
\hline $\mathrm{ADTT}^{4}{ }^{\%} \%$ of intake & 58.1 & 60.0 & 60.6 & 65.3 & 3.6 & 0.10 & 0.15 & NS \\
\hline
\end{tabular}

\footnotetext{
${ }^{1}$ Alfalfa forage was harvested at a theoretical chop length of 19.1 and $7.9 \mathrm{~mm}$ for long and short cut silages, respectively.

${ }^{2} \mathrm{NS}=P>0.15$.

${ }^{3} \mathrm{RFOM}=$ ruminally fermented OM.

${ }^{4} \mathrm{ADTT}=$ apparent digestibility in the total tract.
}

tract with increased FPL resulted from improved NDF digestion in the rumen. Ruminal fiber digestibility was highly correlated with dietary particle length when expressed as pef $_{8.0}$ or peNDF ${ }_{8.0}(\mathrm{r}=0.58)$ in contrast to dietary NDF content $(\mathrm{r}=0.33, P>0.15)$ or intake of forage ( $\mathrm{r}=0.46, P<0.08$; data not shown).

Thus, the improvement in ruminal fiber digestion with increased dietary FPL or increased F:C ratio resulted from an increased physically effective fiber content of the diet, which improved the rumen function of the cows. Increased peNDF intake can increase chewing time and salivary buffering, thereby elevating ruminal $\mathrm{pH}$ (Beauchemin et al., 2003). Furthermore, increased peNDF intake can shift starch digestion from the rumen to the intestine (Fernandez et al., 2004; Yang and Beauchemin, 2006a). In our study, diets with longer FPL ( $\mathrm{pH}=6.36$ and 6.16 for long and short FPL, respectively) or higher $\mathrm{F}: \mathrm{C}$ ratio $(\mathrm{pH}=6.51$ and 6.02 for high and low F:C, respectively) had higher mean ruminal $\mathrm{pH}$ (Yang and Beauchemin, 2007). At least part of the elevation of ruminal $\mathrm{pH}$ with increased $\mathrm{F}$ :C ratio was due to decreased starch intake and decreased ruminal starch digestibility.

\section{N Metabolism}

An interaction between F:C ratio and FPL tended ( $P$ $<0.10)$ to occur for N intake; increased FPL increased $(P<0.07) \mathrm{N}$ intake with low, but not with high, F:C ratio diets (Table 6). This interaction reflected the higher DMI (Table 4) of cows fed low F:C and slightly higher $\mathrm{N}$ content of the long FLP diet (Table 3). Duodenal flows of total, NAN, rumen undegradable N (measured as the feed plus endogenous fraction), and microbial $\mathrm{N}$ were decreased by $15,16,11$, and $19 \%$, respectively, with increased $\mathrm{F}: \mathrm{C}$ ratio. Higher flows of $\mathrm{N}$ to the duodenum with the low F:C diet were due to the combination of higher intake and higher $\mathrm{N}$ recycled into the rumen. Increased ruminal microbial $\mathrm{N}$ production was consistent with the higher amount of OM fermented in the rumen (Table 5). However, there were no effects of $\mathrm{F}$ : $\mathrm{C}$ ratio on ruminal degradation or intestinal digestibility of $\mathrm{N}$ even though total digestibility of $\mathrm{N}$ tended $(P<0.10)$ to be reduced with increased dietary F:C ratio. The present results are consistent with other studies (Khorasani et al., 2001; Moorby et al., 2006) reporting that an increased $\mathrm{F}: \mathrm{C}$ ratio reduced the $\mathrm{N}$ supplied to the duodenum. 
Table 7. Effects of forage-to-concentrate ratio and forage particle size on milk production and composition of lactating dairy cows $(\mathrm{n}=12)$

\begin{tabular}{|c|c|c|c|c|c|c|c|c|}
\hline \multirow[b]{3}{*}{ Item } & \multicolumn{4}{|c|}{ Forage $^{1}$ :concentrate (F:C) } & \multirow[b]{3}{*}{$\mathrm{SE}$} & \multirow{2}{*}{\multicolumn{3}{|c|}{ Effect }} \\
\hline & \multicolumn{2}{|c|}{$35: 65$} & \multicolumn{2}{|c|}{$60: 40$} & & & & \\
\hline & Short & Long & Short & Long & & $\mathrm{F}: \mathrm{C}$ & $\mathrm{F}^{1}$ & $\mathrm{~F}: \mathrm{C} \times \mathrm{F}$ \\
\hline \multicolumn{9}{|c|}{ Milk yield, $\mathrm{kg} / \mathrm{d}$} \\
\hline Actual & 33.5 & 33.2 & 30.8 & 31.3 & 2.7 & 0.01 & NS & NS \\
\hline $4 \% \mathrm{FCM}$ & 30.6 & 30.4 & 30.1 & 30.3 & 3.0 & $\mathrm{NS}$ & NS & NS \\
\hline SCM & 30.7 & 30.6 & 29.2 & 29.4 & 3.0 & 0.02 & NS & NS \\
\hline \multicolumn{9}{|l|}{ Milk fat } \\
\hline$\%$ & 3.45 & 3.44 & 3.84 & 3.80 & 0.16 & 0.01 & NS & NS \\
\hline $\mathrm{kg} / \mathrm{d}$ & 1.15 & 1.14 & 1.18 & 1.18 & 0.13 & 0.11 & NS & NS \\
\hline \multicolumn{9}{|l|}{ Milk protein } \\
\hline$\%$ & 3.34 & 3.36 & 3.07 & 3.09 & 0.07 & 0.01 & NS & NS \\
\hline $\mathrm{kg} / \mathrm{d}$ & 1.11 & 1.11 & 0.94 & 0.96 & 0.10 & 0.01 & NS & NS \\
\hline \multicolumn{9}{|l|}{ Milk lactose } \\
\hline$\%$ & 4.65 & 4.66 & 4.62 & 4.61 & 0.05 & 0.03 & NS & NS \\
\hline $\mathrm{kg} / \mathrm{d}$ & 1.56 & 1.55 & 1.42 & 1.44 & 0.13 & 0.01 & NS & NS \\
\hline \multicolumn{9}{|c|}{ Milk efficiency } \\
\hline Actual:DMI & 1.40 & 1.40 & 1.41 & 1.45 & 0.05 & NS & NS & NS \\
\hline FCM:DMI & 1.27 & 1.28 & 1.38 & 1.41 & 0.05 & 0.01 & NS & NS \\
\hline $\mathrm{SCC} \times 10^{5}$ & 1.19 & 1.22 & 1.25 & 1.37 & 0.54 & NS & NS & NS \\
\hline
\end{tabular}

${ }^{1}$ Alfalfa forage was harvested at a theoretical chop length of 19.1 and $7.9 \mathrm{~mm}$ for long and short cut silages, respectively.

Effects of FPL on flows of total N, NAN, undegraded $\mathrm{N}$, and microbial $\mathrm{N}$ to the duodenum were not significant (Table 6). Ruminal degradability and intestinal digestibility of $\mathrm{N}$ were also similar between short and long FPL, although the total digestibility of $\mathrm{N}$ was numerically $(P<0.15)$ increased by about $6 \%$ with longer FPL. The effects of FPL of alfalfa-based diets on N metabolism in the digestive tract of cattle are inconclusive in the literature (Krause et al., 2002a; Yang et al., 2002; Kononoff and Heinrichs, 2003b); total digestibility of $\mathrm{N}$ with increasing dietary FPL was increased in the study of Yang et al. (2002) but was reduced in the study of Kononoff and Heinrichs (2003b). Krause et al. (2002a) reported that microbial $\mathrm{N}$ supply depended on the availability of ruminal fermentable energy. Those researchers found that with increasing dietary FPL, microbial $\mathrm{N}$ supply increased in high-moisture corn diets but decreased with dry corn diets because cows fed high-moisture corn had higher starch intake, whereas cows fed dry corn had lower starch intake when FPL was increased. In the present study, starch intake and OM fermented in the rumen were not affected by dietary FPL. Digestibility of $\mathrm{N}$ in the intestine or in the total tract likely varies with the relative proportion of microbial $\mathrm{N}$ and dietary $\mathrm{N}$ arriving at the duodenum.

\section{Milk Production and Composition}

Actual milk yield and SCM production were decreased with an increased F:C ratio (Table 7), confirming other studies (Yang et al., 2001; Moorby et al., 2006).
This decrease in milk production was consistent with lower DMI and lower intake of digestible OM in the total tract. However, FCM production was similar for cows fed low and high $\mathrm{F}: \mathrm{C}$ ratio diets. The increase in milk fat content with increased F:C ratio was offset by a corresponding decrease in milk production. This finding confirms our previous results with barley-based diets (Yang et al., 2001). Lower milk fat for cows fed low F:C diets than for those fed high F:C diets reflects differences in ruminal digestion. Cows fed a low $\mathrm{F}: \mathrm{C}$ diet had lower ruminal $\mathrm{pH}(\mathrm{pH}=6.51$ and 6.02 for high and low F:C, respectively) and higher molar proportion of propionate (\% of propionate $=20.2$ and 30.6 for high and low F:C, respectively; Yang and Beauchemin, 2007). Contents of milk protein and milk lactose were decreased from 3.35 to $3.08 \%$ and from 4.66 to $4.62 \%$, respectively, with increased $\mathrm{F}: \mathrm{C}$ ratio. As a result, production of milk protein and lactose was decreased by 14 and 8\%, respectively. An improvement of milk protein content with decreased F:C ratio was likely due to an increased supply of energy and N. A larger quantity of starch was digested in the rumen and in the intestine, which might have provided more propionate for glucose synthesis and more glucose for absorption in the intestine. The relationship between dietary energy supply and milk protein concentration is well documented (Sutton, 1989); an energy deficit can depress protein percentage by 0.1 to 0.4 percentage units. Mackle et al. (2000) suggested that the mechanism by which an increased dietary energy level influences milk protein 
is related to increased microbial $\mathrm{N}$ synthesis in the rumen, as well as to increased blood insulin.

Milk yield and milk composition were not affected by dietary FPL (Table 7), which is not surprising considering the lack of response of DMI and OM digestibility in the total tract. Similarly, milk production did not respond to FPL in other metabolism studies that used corn silage (Kononoff and Heinrichs, 2003a; Yang and Beauchemin, 2005) or AS (Kononoff and Heinrichs, $2003 \mathrm{~b})$. Responses in milk production primarily reflect changes in DMI or starch intake when FPL is altered (Krause et al., 2002a).

The lack of response of milk fat to dietary FPL suggests that the diets contained adequate fiber to maintain milk fat percentage. Milk fat depression is more likely to occur when NDF is below the minimum requirements. The dietary NDF contents in the present study met the NRC recommendation (2001), which is based on corn diets. For diets containing barley grain, Beauchemin and Yang (2003) recommended (\% of TMR, DM basis) a minimum NDF from forage sources of 21 to $23 \%$ and a maximum starch content of $33 \%$. The NDF from forage (16\%) in the present study was below that recommendation, but this was offset by a lower starch content $(30.6 \%)$ than the upper recommended level. Several studies also reported no response of milk fat to altering FPL of AS (Krause et al., 2002a; Beauchemin et al., 2003; Kononoff and Heinrichs, 2003b). It appears that peNDF is not a good predictor of milk fat because many factors affect milk fat content (Allen, 1997).

\section{CONCLUSIONS}

Particle length and peNDF content of dairy cow diets were altered by changing the forage proportion, length of forage particles, or both. Increasing the dietary peNDF content by increasing the FPL significantly improved fiber digestion in the rumen and in the total tract. Increasing the proportion of forage in the diet increased fiber intake and its digestibility in the rumen and total tract, but DMI, ruminal starch availability, and microbial N synthesis were reduced. Although actual milk production declined with increased dietary $\mathrm{F}: \mathrm{C}$ ratio, $4 \% \mathrm{FCM}$ production was not affected because of higher milk fat. The strong relationship between peNDF intake and fiber digestibility in the rumen and in the total tract suggests that intake of dietary peNDF may be a reliable indicator of fiber digestion. The present study demonstrated that there are minimal interactions between the effects of proportion of forage in the diet and length of forage particles on feed intake, digestion, and milk production. Increasing the intake of long forage particles by increasing the proportion of forage in the diet or by increasing the chop length of forage improves fiber digestion and utilization because of improved rumen fermentation.

\section{ACKNOWLEDGMENTS}

This experiment was financially supported by the Dairy Farmers of Canada (Ottawa, Ontario) and Agriculture and Agri-Food Canada's Matching Investment Initiative. The authors thank K. Andrews, B. Farr, A. Furtado, D. Vedres, and R. Wuerfel for their assistance in performing sampling and laboratory analyses, as well as the staff of the Lethbridge Research Centre dairy unit for care of the cows and milk sample collection.

\section{REFERENCES}

Allen, M. S. 1997. Relationship between fermentation acid production in the rumen and the requirement for physically effective fiber. J. Dairy Sci. 80:1447-1462.

Allen, M. S., and D. R. Mertens. 1988. Evaluating constraints on fiber digestion by rumen microbes. J. Nutr. 118:261-270.

AOAC (Association of Official Analytical Chemists). 1990. Official Methods of Analysis. Vol. 1. 15th ed. AOAC, Arlington, VA.

Beauchemin, K. A., and W. Z. Yang. 2003. Forage: How much do dairy cows need in a time scarcity? Adv. Dairy Technol. 15:261-274.

Beauchemin, K. A., and W. Z. Yang. 2005. Effects of physically effective fiber on intake, chewing activity, and ruminal acidosis for dairy cows fed diets based on corn silage. J. Dairy Sci. 88:2117-2129.

Beauchemin, K. A., W. Z. Yang, and L. M. Rode. 2003. Effects of particle size of alfalfa-based dairy cow diets on chewing activity, rumen fermentation, and milk production. J. Dairy Sci. 86:630-643.

Fernandez, I., C. Martin, M. Champion, and B. Michalet-Doreau. 2004. Effect of corn hybrid and chop length of whole-plant corn silage on digestion and intake by dairy cows. J. Dairy Sci. 87:1298-1309.

Kalscheur, K. F., B. B. Teter, L. S. Piperova, and R. A. Erdman. 1997. Effects of dietary forage concentration and buffer addition on duodenal flow of trans-C18:1 fatty acids and milk fat production in dairy cows. J. Dairy Sci. 80:2104-2114.

Khorasani, G. R., E. K. Okine, and J. J. Kennelly. 2001. Effects of forage source and amount of concentrate on rumen and intestinal digestion of nutrients in late-lactation cows. J. Dairy Sci. 84:1156-1165.

Kononoff, P. J., and A. J. Heinrichs. 2003a. The effect of corn silage particle size and cottonseed hulls on cows in early lactation. J. Dairy Sci. 86:2438-2451.

Kononoff, P. J., and A. J. Heinrichs. 2003b. The effect of reducing alfalfa haylage particle size on cows in early lactation. J. Dairy Sci. 86:1445-1457.

Kononoff, P. J., A. J. Heinrichs, and D. R. Buckmaster. 2003. Modification of Penn State forage and total mixed ration particle separator and the effects of moisture content on its measurements. J. Dairy Sci. 86:1858-1863.

Krause, K. M., D. K. Combs, and K. A. Beauchemin. 2002a. Effects of forage particle size and grain fermentability in midlactation cows. I. Milk production and diet digestibility. J. Dairy Sci. 85:1936-1946.

Krause, K. M., D. K. Combs, and K. A. Beauchemin. 2002b. Effects of forage particle size and grain fermentability in midlactation cows. II. Ruminal $\mathrm{pH}$ and chewing activity. J. Dairy Sci. 85:1947-1957. 
Lammers, B. P., D. R. Buckmaster, and A. J. Heinrichs. 1996. A simple method for the analysis of particle sizes of forage and total mixed rations. J. Dairy Sci. 79:922-928.

Llamas-Lamas, G., and D. K. Combs. 1991. Effects of forage to concentrate ratio and intake level on utilization of early vegetative alfalfa silage by dairy cows. J. Dairy Sci. 74:526-536.

Mackle, T. R., D. A. Dwyer, K. L. Ingvartsen, P. Y. Chouinard, D. A. Ross, and D. E. Bauman. 2000. Effects of insulin and postruminal supply of protein on use of amino acids by the mammary gland for milk protein synthesis. J. Dairy Sci. 83:93-105.

Mertens, D. R. 1997. Creating a system for meeting the fiber requirements of dairy cows. J. Dairy Sci. 80:1463-1481.

Moorby, J. M., R. J. Dewhurst, R. T. Evans, and J. L. Danelon. 2006. Effects of dairy cow diet forage proportion on duodenal nutrient supply and urinary purine derivative excretion. J. Dairy Sci. 89:3552-3562.

NRC (National Research Council). 2001. Nutrient Requirements of Dairy Cattle. 7th rev. ed. Natl. Acad. Sci., Washington, DC.

Nocek, J. E. 1997. Bovine acidosis: Implication on laminitis. J. Dairy Sci. 80:1005-1028.

Owens, F. N., D. S. Secrist, W. J. Hill, and D. R. Gill. 1998. Acidosis in cattle: A review. J. Anim. Sci. 76:275-286.

Rode, L. M., W. Z. Yang, and K. A. Beauchemin. 1999. Fibrolytic enzyme supplements for dairy cows in early lactation. J. Dairy Sci. 82:2121-2126.

SAS Institute. 1996. SAS User's Guide: Statistics. Version 7 Edition. SAS Inst., Inc., Cary, NC.

Soita, H. W., D. A. Christensen, J. J. McKinnon, and A. F. Mustafa. 2002. Effects of barley silage of different theoretical cut length on digestion kinetics in ruminants. Can. J. Anim. Sci. 82:207-213.

Soita, H. W., M. Fehr, D. A. Christensen, and T. Mutsvangwa. 2005. Effects of corn silage particle length and forage:concentrate ratio on milk fatty acid composition in dairy cows fed supplemental flaxseed. J. Dairy Sci. 88:2813-2819.

Sutton, J. D. 1989. Altering milk composition by feeding. J. Dairy Sci. 72:2801-2814.

Van Soest, P. J., J. B. Robertson, and B. A. Lewis. 1991. Methods for dietary fiber, neutral detergent fiber and non-starch polysaccharide in relation to animal nutrition. J. Dairy Sci. 74:35833597.

Yang, W. Z., and K. A. Beauchemin. 2005. Effects of physically effective fiber on digestion and milk production by dairy cows fed diets based on corn silage. J. Dairy Sci. 88:1090-1098.

Yang, W. Z., and K. A. Beauchemin. 2006a. Increasing the physically effective fiber content of dairy cow diets may lower efficiency of feed use. J. Dairy Sci. 89:2694-2704.

Yang, W. Z., and K. A. Beauchemin. 2006b. Physically effective fiber: Method of determination and effects on chewing, ruminal acidosis, and digestion by dairy cows. J. Dairy Sci. 89:2618-2633.

Yang, W.Z., and K. A. Beauchemin. 2007. Altering physically effective fiber intake through forage proportion and particle length: Chewing and ruminal pH. J. Dairy Sci. 90:2826-2838.

Yang, W. Z., K. A. Beauchemin, and L. M. Rode. 2001. Effects of grain processing, forage to concentrate ratio, and forage particle size on rumen $\mathrm{pH}$ and digestion by dairy cows. J. Dairy Sci. 84:2203-2216.

Yang, W. Z., K. A. Beauchemin, and L. M. Rode. 2002. Effects of particle size of alfalfa-based dairy cow diets on site and extent of digestion. J. Dairy Sci. 85:1958-1968.

Yansari, A. T., R. Valizadeh, A. Naserian, D. A. Christensen, P. Yu, and F. E. Shahroodi. 2004. Effects of alfalfa particle size and specific gravity on chewing activity, digestibility, and performance of Holstein dairy cows. J. Dairy Sci. 87:3912-3924. 